\title{
Will 'structural reforms' of labour markets reduce productivity growth? A firm-level investigation
}

\author{
Robert Vergeer* \\ TNO (Netherlands Organisation for Applied Scientific Research), Leiden, The Netherlands
}

Steven Dhondt

TNO (Netherlands Organisation for Applied Scientific Research), Leiden, The Netherlands and Professor of Sociology, Catholic University of Leuven, Belgium

Alfred Kleinknecht

Emeritus Professor of Economics, TU Delft and Fellow of WSI, Hans Böckler Foundation, Düsseldorf, Germany

\section{Karolus Kraan}

TNO (Netherlands Organisation for Applied Scientific Research), Leiden, The Netherlands

More 'flexible' labour relations significantly reduce labour productivity growth in sectors that tend towards a 'routinised' (other than a 'garage business') innovation regime. We argue that structural reforms that make firing easier will diminish the loyalty and commitment of workers, making accumulation of (tacit) knowledge more difficult. It also reduces training, increases knowledge-leaking to competitors and favours autocratic management and the growth of management and control bureaucracies. Our results are consistent with findings in macro-level studies that wage-cost saving flexibilisation of labour relations and downward wage flexibility reduce labour productivity growth: a 1 per cent wage change causes $a \approx 0.4$ per cent change in value added per labour hour.

Keywords: flexible labour, labour productivity, innovation regimes, varieties of capitalism

JEL codes: $J 5, O 3$

\section{INTRODUCTION}

Mainstream economics insists that unemployment has to be explained primarily by labour market rigidities. According to the logic of a declining demand curve for labour, downwardly flexible wages would increase employment by allowing the creation of jobs with lower pay and lower productivity. If only wages were downwardly flexible, unemployment could be reduced. Among the obstacles in the way of downward wage flexibility are generous social benefits, high minimum wages, the power of insiders, or strong trade unions.

* $\quad$ Our research was funded by TNO (Netherlands Organisation for Applied Scientific Research) under the program Social Innovation Management 2013.

Received 16 May 2014, accepted 18 December 2014 
Practical examples of how to remove labour market rigidities are the UK and the US under Thatcher and Reagan or the deregulation of labour markets in countries like Australia or New Zealand. Such structural reforms typically resulted in trimming social benefits, in reducing the power of trade unions or in decentralised wage bargaining and greater income inequality. A downside is the emergence of larger groups of 'working poor', but this has been legitimised by the argument that a bad job is still better than no job.

Section 2 of this paper discusses the arguments for and against the proposition that deregulation of labour markets can positively or negatively influence innovation, and draws from the Varieties-of-Capitalism literature (Albert 1993; Hall/Soskice 2001). Several empirical studies suggest that the deregulation of labour markets has a negative impact on labour productivity growth and innovation (see for example Acharya et al. 2010; Auer et al. 2005; Buchele/Christiansen 1999; Kleinknecht et al. 2006; Lucidi/Kleinknecht 2010; Martínez-Sánchez et al. 2008; Michie/Sheehan 2001; 2003; Pieroni/Pompei 2008; RocaPuig et al. 2012). But a single study arrives at insignificant results (Arvanitis 2005) or even concludes the opposite (Bassanini et al. 2009). We propose that past studies might have missed an important control variable: the dominant innovation regime in a firm's sector of principal activity. In other words, is innovation in a sector predominantly characterised by 'garage business' or does it follow a 'routinised' innovation regime? We propose that flexible labour relations in Anglo-Saxon style might be compatible with garage business innovation, while the functioning of a routinised innovation regime might be favoured by 'rigid' Old Europe style labour relations.

We test this using firm-level data from the Netherlands. The Netherlands are an interesting case as formal labour laws provide an Old Europe style protection against firing for tenured workers, and the country's welfare state still provides a degree of social protection that exceeds Anglo-Saxon standards. During the past 30 years, however, a fringe of outsiders has been formed consisting of people on various types of flexible contracts. At present, the share of flexible workers amounts to 23-35 per cent of the country's labour force, depending on the state of the business cycle and on statistical definitions (Dekker et al. 2012). In practice, there are substantial inter-firm differences in the use of flexible work. The inter-firm variation in the use of flexible contracts (within one country that is, under identical national labour market institutions) allows for testing which type of firm is performing better. A novelty in our approach is the use of a new indicator that rates a firm's sector of principal activity according to the degree to which the sector tends more towards a 'garage business' innovation model or more towards a 'routinised' innovation model.

The paper is structured as follows. Section 2 provides a discussion on why and how flexible labour markets should have an impact on innovations and productivity. Sections 3 and 4 present our model and empirical estimates. Section 5 rounds up with conclusions.

\section{WHY AND HOW COULD FLEXIBLE LABOUR IMPACT ON INNOVATION AND PRODUCTIVITY?}

\subsection{Arguments why flexible labour could favour innovation and productivity}

In the literature, there are seven arguments that more flexibility in labour relations may favour innovation and productivity. First, ease of firing will make it easier to reallocate labour from old and declining sectors to new and dynamic ones (see for example Nickell/Layard 1999). Second, the difficult or expensive firing of redundant personnel 
can frustrate labour-saving innovations at the firm level (Bassanini/Ernst 2002; Scarpetta/Tressel 2004). Third, well-protected and powerful personnel could appropriate rents from innovation through higher wage claims, thus reducing incentives for taking innovative risks (Malcomson 1997). Fourth, firms will more easily engage in risky new ventures if they can easily shed their personnel in the case of failure (Bartelsman et al. 2012). Fifth, easier firing will increase rates of job turnover, allowing for more 'job-matches'. This increases the chance that people will find the jobs in which they are most productive. Sixth, higher labour turnover enhances the inflow of 'fresh blood': people with new ideas and new networks may foster innovation. This means that there is less chance that employees will be entrenched in safe jobs, gradually losing their creativity. Finally, the (latent) threat of easy firing may prevent 'shirking'.

Against such arguments, several objections are possible. Regarding the first argument, emerging new industries are likely to offer better carrier opportunities and higher pay than declining industries. Why should we not rely on the fact that such incentives will make people move voluntarily? And if workers from a declining coal mine do not move into the IT industry, is it really firing-protection in the coal mine that hinders them? Regarding the second argument, rates of job turnover have been estimated as being around 9-12 per cent in the Netherlands (Kleinknecht et al. 2006); also Nickell/Layard (1999: 363) report a figure over 10 per cent. Such percentages offer some room for downsizing without forced leave. Moreover, if firing is difficult, firms have incentives to invest in functional flexibility by means of training, which will allow the shifting of labour from old to new activities in internal labour markets. In other words, lack of firing flexibility will enhance functional flexibility. Note that Acemoglou/Pischke (1999) argue that wage compression (a labour market rigidity!) in rigid German labour markets enhances training for highly educated and for low-educated workers, while in the liberalised US system, it is mainly highly educated workers who receive training.

The third argument, about labour appropriating innovation profits through wage claims, is relevant in decentralised wage-bargaining settings, typical for Anglo-Saxon labour markets. 'Rhineland'-type labour markets rely more on industry-level bargaining in which wage bargains are often imposed by government on everyone in a sector. Incidentally, such a labour market rigidity can actually enhance innovation, as technological laggards are forced into making productivity-increasing investments in response to rising wages. The fourth argument, by Bartelsman et al. (2012), may be relevant, as it allows the shifting of part of the entrepreneurial risks to employees. This may notably encourage garage business innovation in young and fragile firms. The same holds for the 'fresh blood' argument: if firms rely on readily available general knowledge in a garage business model, a higher job turnover may be helpful for innovation. It may, however, be counterproductive in a 'routinised' Schumpeter II model when continuous accumulation of knowledge is crucial (see below).

\subsection{Arguments why flexible labour could damage innovation and productivity}

First, Vergeer/Kleinknecht (2011) demonstrated that, during the past 30 years, the 'rigid' labour markets of 'Old Europe' showed substantially higher increases in wages and in labour productivity compared to 'flexible' Anglo-Saxon-type labour markets in which easy firing and modest social benefits restrict the power of labour. Higher labour productivity gains in 'Old Europe' may have been caused by stronger substitution of capital for labour and by vintage effects: old vintages of capital need to be replaced more quickly as they become less profitable with rising wages. Lower wage increases 
can result in a growing age of capital stock, which has been shown as being one of the reasons behind the labour productivity crisis in the Netherlands after 1982 when trade unions voluntarily sacrificed wages against the promise of more jobs (see Naastepad/Kleinknecht 2004).

Second, in a Schumpeterian perspective, it can be argued that, due to their monopoly rents from innovation, innovators are better able than technological laggards to live with wage increases (or with high adjustment costs due to stricter regulation). Therefore, high real wage growth and labour market rigidities support the Schumpeterian process of creative destruction in which innovators compete away technological laggards (Kleinknecht 1998).

Third, easy firing and higher labour turnover shorten the payback period of a firm's investment in manpower training. In addition, workers will be more interested in acquiring general skills that increase their employability on the external job market, but may be reluctant to acquire firm-specific skills if there is no long-term commitment to their firm (Belot et al. 2002). A similar conclusion emerges from the hypothesis that highly flexible labour reduces the compression of the wage structure (both within and between firms); note that Acemoglu/Pischke (1999) and Agell (1999) argue that wage compression is a reason for the provision of training by firms.

Fourth, work by Buchele/Christiansen (1999), Huselid (1995), Lorenz (1999), Michie/Sheehan $(2001 ; 2003)$ and Naastepad/Storm (2006) suggests there are favourable productivity effects of 'high trust' or 'high road' human resource management practices. Svensson (2011) shows empirically that non-typical (or 'flexible') employment reduces trust. Higher trust, loyalty and commitment favour productivity growth in four ways: (i) they reduce transaction costs (for example, Naastepad/Storm (2006: 170-191) demonstrate that firms in low-trust 'Anglo-Saxon' countries have substantially thicker management bureaucracies for monitoring and control, compared to 'Rhineland' countries); (ii) greater loyalty of personnel reduces positive externalities (that is, the leaking of trade secrets to competitors); (iii) more continuity of personnel favours the long-run historical accumulation of knowledge in a 'routinised' innovation model (see Table 1) (some of that knowledge is 'tacit', that is, it is knowledge from practical experience that tends to be poorly documented or codified, being stored at people's fingertips, and is not 'owned'

Table 1 Stylised comparison of two Schumpeterian innovation models

\begin{tabular}{ll}
\hline $\begin{array}{c}\text { Schumpeter I model:* } \\
\text { 'garage business innovation' }\end{array}$ & $\begin{array}{c}\text { Schumpeter II model:** } \\
\text { 'routinised innovation' }\end{array}$ \\
\hline Starters in high tech; niche players & $\begin{array}{c}\text { Established firms with professionalised } \\
\text { R\&D labs } \\
\text { Monopolistic competitors; oligopolists } \\
\text { SMEs and young firms }\end{array}$ \\
$\begin{array}{l}\text { Stable hierarchy of (dominant) innovators } \\
\text { Properties of the knowledge base ... }\end{array}$ & $\begin{array}{c}\text { Dependence on historically accumulated and } \\
\text { General and generally available } \\
\text { knowledge } \rightarrow \text { low entry barriers } \\
\text { entry barriers }\end{array}$
\end{tabular}

\section{... and complementary labour market institutions}

Recruitment through external labour Internal labour markets $\rightarrow$ well-protected markets 'insiders'

Notes:

* Schumpeter (1912).

** Schumpeter (1943). 
by the firm and is hard to transfer, except by personal interaction (see Polanyi 1966)); and (iv) better protection against firing will favour critical feedback to bosses from the shop floor. Powerful bosses tend to surround themselves with yes-men. If this is enhanced by a change of power relations due to easier firing, it can favour autocratic management practices.

Fifth, an argument closely related to the previous one comes from Acharya et al. (2010: 1), who argue that stringent labour laws provide firms with a 'commitment device' to avoid punishing short-run failures and this would encourage employees pursuing more risky and value-enhancing innovative activities. Exploiting time-series variation in changes of dismissal laws, they find that innovation and growth are fostered by stringent laws governing dismissal of employees, especially in the more innovation-intensive sectors. Firm-level tests within the United States that exploit a discontinuity generated by the passage of the federal Worker Adjustment and Retraining Notification Act confirm the cross-country evidence' (ibid.: 1).

Sixth, Lorenz (1999) argues that protection against dismissal may enhance productivity performance, as secure workers will be more willing to cooperate with management in developing labour-saving processes and in disclosing their (tacit) knowledge to the firm. More generally, workers who are easy to fire have incentives to hide information about how their work can be done more efficiently, exploiting information asymmetries between shop floor and (top) management. In other words, a flexible firing system is likely to make poor use of (tacit) knowledge on the shop floor for implementation of more efficient work practices.

Finally, rigid labour markets favour the long-run historical accumulation of (tacit) knowledge in a 'routinised' (Schumpeter II) innovation model. The argument about 'entrepreneurial' versus 'routinised' innovation regimes is summarised in Table 1, which is inspired by the work of Breschi et al. (2000).

The above-sketched arguments for and against the hypothesis that flexible labour may damage (or enhance) innovation call for empirical tests. In the remainder of this paper we shall provide one such test, using firm-level data from the Netherlands. While many of the above arguments relate to innovation in general, we confine our test to a proxy of the outcomes of the innovative process - that is, growth of value added per full-time employee (labour productivity growth).

\section{OUR MODEL AND INDICATORS}

Our model should answer two questions: (i) Is there a relationship between flexibility practices and labour productivity performance? And (ii) how does the innovation regime in the firm's sector of principal activity moderate this relationship? We explain labour productivity growth from 2008 to 2009 with explanatory variables measured in 2008 or before. The reader should note that the choice of years is a bit unfortunate, as we had the Lehman Crash in September 2008, followed by a deep recession that lasted well into 2009. The Lehman Crash is unlikely to have had a profound influence on our estimates (except, of course, that the crash is likely to have reduced value added in all firms towards the end of 2008), but firms may have fired people in 2009, as problems continued. This is likely to bias our estimates: firms with many flexible workers may have pared down their personnel more quickly during 2009. As we divide value added through personnel, this may result in more favourable labour productivity growth rates in the more flexible firms in 2009, which may bias our results against the hypothesis that the latter realise lower productivity growth. 
Value added is calculated as the sum of wages and profits at the firm level, taken from balance-sheet statistics for non-financial firms (NFO) gathered by Statistics Netherlands (CBS), divided by full-time equivalents of personnel. Full-time employees at the firm level are calculated from wage tax registration statistics (in Dutch: 'loonaangifte statistieken') also gathered by Statistics Netherlands.

A frequent drawback in empirical studies based on surveys is common method bias (Podsakoff et al. 2003). That is, a bias can be introduced as the same respondent subjectively assesses indicators that inform both right-hand and left-hand variables. We deal with the common method bias by linking subjectively assessed explanatory variables to objectively measured performance variables that stem from two different sources (see Appendix 1 for details). Moreover, we control for a baseline effect by including lagged levels of labour productivity. This can be interpreted to model two opposing phenomena. First, there may be a mean reversion effect. Thus, firms that have already achieved high levels of productivity may have less room for improvement as they are close to the best-practice frontier. Second, firms that perform better than average may, in addition to their HRM practices, also do other things systematically better than their counterparts. Thus, they might perhaps improve even more than their peers.

Finally, we add a number of control variables that are commonly used in innovationrelated regressions. Our three explanatory variables of interest are the following:

\section{Internal labour flexibility}

Internal (or 'functional') flexibility was measured at the firm level, using the mean value for the following five questions from The Netherlands Employers Work Survey (see Appendix 1 for details):

i. 'To what extent is there room for individual, tailor-made arrangements concerning working time schedules for your employees?';

ii. 'To what extent is there room for individual, tailor-made arrangements concerning work processes for your employees?';

iii. 'To what extent does your organisation apply multi-functional use of personnel?';

iv. 'To what extent does your organisation apply flexible working schedules?'; and

v. 'To what extent does your organisation apply self-scheduling of shifts?'.

For items i and ii, response categories ranged from (1) 'very little/no room' to (5) 'a lot of room'. For items iii to v, response categories ranged from (1) 'not at all' to (5) 'to a very large extent'. Cronbach's $\alpha$ of this five-item scale is 0.77 . The items correspond to our theoretical notions about dimensions of internal flexibility, such as flexible working schedules, job rotation, allowing for individual tailor-made arrangements about the job and influence of workers on schedules. We expect high internal (or 'functional') flexibility to exert a positive influence on labour productivity.

\section{External labour flexibility}

External (or numerical) labour flexibility at the firm level is calculated as the sum of full-time equivalents of employees on temporary contracts, of manpower agency workers and of flexitime contracts (that is, people whose working time can range from zero hours to full-time, depending on the employer's needs), divided by the sum of all employees (in full-time equivalents). All data are taken from the Wage Tax Registrations Statistics (see Appendix 1). 


\section{Innovation regimes}

A novelty of this paper is the proposition that the relationship between flexible work and productivity growth is moderated by the type of innovation regime in a firm's sector of principal activity. As a proxy of the extent to which an industry is 'Schumpeter I' or 'Schumpeter II' (see Table 1) we take the concentration of R\&D budgets in an industry, using the well-known Herfindahl-Hirschman Index (HHI). In other words, every industry receives a value on a continuous scale between 0 (perfect dispersion of R\&D) and 1 (perfect concentration). Values closer to zero indicate a Schumpeter I garage business model; values closer to 1 indicate a Schumpeter II model with a few dominant innovators. The indicator has been developed and tested for the first time in Kleinknecht et al. (2014) and is calculated from Community Innovation Survey (CIS) data available at Statistics Netherlands, taking averages over the years 1998-2008 in 26 manufacturing and commercial service sectors. This is an admittedly rough measure of innovation regimes, assuming that in typical garage business sectors, R\&D may be somehow scattered across firms, while in sectors that tend towards a routinised innovation regime, we assume market structure (and R\&D) to be more concentrated, thanks to long-run knowledge accumulation and economies of scale to knowledge capital that favour oligopolistic market structures.

We are interested in interactions between the HHI index of concentration of R\&D in a firm's sector of principal activity and shares of flexible workers at firm level. Firms in sectors that tend towards 'garage business' ('Schumpeter I') are expected to benefit from employing flexible labour and experience higher labour productivity growth, while the combination of a 'Schumpeter II' innovation regime and flexibility is expected to reduce labour productivity growth. We calculate the interaction term based on centred values of the individual variables (Aiken/West 1991), in order to prevent multicollinearity problems.

We control for four broad sectors: (i) manufacturing and agriculture; (ii) construction; (iii) services: health care and welfare, education and remaining business services; and (iv) other services (that is, hotels and catering, transport and communication, financial services and trade).

Finally, we control for company age (natural log) and for company size: very small (2-4 employees), small (5-9 employees), medium and large (10 employees and more). Moreover, following other studies in the field (Martínez-Sánchez et al. 2008; Roca-Puig et al. 2012), we include the educational achievements of employees; that is, the percentages of personnel having lower or medium-level education (reference group: higher education). Finally, we include levels of labour productivity in 2008 to correct for baseline effects on productivity.

Descriptive statistics and a correlation table are given in Appendices 2 and 3.

We test the following model:

$$
\begin{aligned}
\widehat{L P}_{t, i}= & \alpha+\beta_{1} \text { IntFlex }_{t-1, i}+\beta_{2} \text { ExtFlex }_{t-1, i}+\beta_{3} \text { ExtFlex }_{t-1, i} * H H I+\beta_{4} H H I \\
& +\vec{\beta}_{5}^{\prime} \overrightarrow{\text { Controls }}_{t-1, i}+\beta_{6} L P_{t-1, i}+\varepsilon_{t, i} .
\end{aligned}
$$

The dependent variable is the growth of labour productivity $\left(\widehat{L P}_{t, i}\right)$ from year 2008 to 2009, at firm level. All independent variables are from 2008 or before. Key independent variables are the above-mentioned indicators for internal (or 'functional') flexibility $\left(\right.$ IntFlex $\left._{t-1, i}\right)$ and external (or 'numerical') flexibility (ExtFlex t-1,i $_{t}$ ). HHI denotes the Herfindahl-Hirschman Index, measuring the extent to which a firm's sector of principal activity shows a lower ('Schumpeter I') or higher ('Schumpeter II') concentration of R\&D. Our key variable of interest is the interaction term of innovation regime and numerical 
(external) flexibility; that is, ExtFlex t $-1, i^{*} H H I$. The interaction variable is calculated using the mean-centring procedure recommended by Aiken/West (1991), as:

$$
\text { ExtFlex }_{t-1, i} * H H I=\left(\text { ExtFlex }_{t-1, i}-\overline{\text { ExtFlex }}_{t-1, i}\right)(H H I-\overline{H H I}),
$$

where the accent $\left(^{-}\right)$denotes the sample mean. Furthermore, we include the level of labour productivity in $2008\left(L P_{t-1, i}\right)$. $\overrightarrow{\text { Controls }}_{t-1, i}$ denotes the vector of control variables. In order not to over-determine the model, sector controls are limited to a rough subdivision into (i) manufacturing, (ii) construction and (iii) services. Controls for company size are limited to inclusion of dummies for firm size classes of 5-9, 10 and more employees (micro firms with 2-4 employees serving as the reference group). $\alpha$ and $\beta$ are (vectors of) coefficients. $\varepsilon_{t, i}$ denotes the error term with standard properties.

We estimate the model by OLS, allowing for heteroscedasticity and autocorrelation in the residuals by calculating HAC standard errors (using the Option 'robust' in Stata). We performed a White test for heteroscedasticity and found this correction appropriate $(\chi 2(91)=118,14 ; p=0.030)$.

\section{RESULTS}

Table 2 summarises our regressions. Descriptive statistics and a correlation table can be found in Appendices 2 and 3. We present four models, starting from a simple model and then adding right-hand variables stepwise. The first model explains labour productivity growth by the indicators for internal and external flexibility plus controls for sectors, firm size, firm age and levels of education. In this simple model, the indicator for internal flexibility is positive at 10 per cent significance level. This is consistent with findings from earlier firm-level studies by Arvanitis (2005) and Kleinknecht et al. (2006). In this simple version, however, the indicator for external flexibility is not significant. This may be explained by lack of control for the type of innovation model. The latter is included in models 2-4. Model 2 includes the interaction of (externally, or numerically) flexible labour with the Herfindahl-Hirschman index for concentration of R\&D, which turns out to be significantly negative. This supports our theoretical expectation: high shares of workers on flexible contracts significantly reduce labour productivity growth in industries that tend towards the 'routinised' Schumpeter II model.

Models 3 and 4 serve as robustness checks. Model 3 includes, besides the standard controls (size, age, education, sectors) another control variable: the level of labour productivity in 2008. The latter shows a negative sign: firms with lower levels have higher growth rates of labour productivity as they take advantage of catching-up effects. This is consistent with earlier productivity estimates both at firm- and at country-level (see for example Lucidi/Kleinknecht 2010; Vergeer/Kleinknecht 2011; 2014). This result is relevant, as one might have argued that we have an endogeneity problem with our flexibility variables: it could be that firms with a bad productivity performance in the past are forced into adopting 'low road' HRM practices; that is, hiring cheap flexible workers. An elegant solution to this endogeneity problem would require the use of panel data. But this is hard to do, given that databases that combine labour market data with innovation and productivity data are extremely scarce. The finding, however, that firms with lower levels show higher growth rates of labour productivity gives at least an indirect indication that a causal chain from low productivity causing more flexible work and thus low productivity gains is not very plausible (although it cannot be safely excluded). 
Table 2 Factors that influence the growth of labour productivity ( $\widehat{\mathrm{LP}}, \mathrm{i})$

\begin{tabular}{|c|c|c|c|c|c|c|c|c|}
\hline \multirow[t]{2}{*}{ Independent variables } & \multicolumn{2}{|c|}{ Model 1} & \multicolumn{2}{|c|}{ Model 2} & \multicolumn{2}{|c|}{ Model 3} & \multicolumn{2}{|c|}{ Model 4} \\
\hline & $\beta$ & $p$ & $\beta$ & $p$ & $\beta$ & $p$ & $\beta$ & $p$ \\
\hline IntFlex $_{t-1, i}$ & $\begin{array}{c}0.058 \\
(1.78)\end{array}$ & 0.075 & $\begin{array}{l}0.058 \\
(1.80)\end{array}$ & 0.073 & $\begin{array}{c}0.055 \\
(1.77)\end{array}$ & $\mathbf{0 . 0 7 7}$ & $\begin{array}{c}0.048 \\
(1.72)\end{array}$ & 0.086 \\
\hline ExtFlex $x_{t-1, i}$ & $\begin{array}{l}-0.055 \\
(-1.02)\end{array}$ & 0.307 & $\begin{array}{l}-0.061 \\
(-1.14)\end{array}$ & 0.255 & $\begin{array}{l}-0.071 \\
(-1.35)\end{array}$ & 0.179 & $\begin{array}{l}-0.078 \\
(-1.51)\end{array}$ & 0.131 \\
\hline ExtFlex $_{t-1, i} * H H I$ & & & $\begin{array}{l}-0.581 \\
(-2.39)\end{array}$ & 0.017 & $\begin{array}{l}-0.681 \\
(-2.64)\end{array}$ & 0.009 & $\begin{array}{l}-0.644 \\
(-2.46)\end{array}$ & 0.014 \\
\hline$H H I$ & & & $\begin{array}{l}-0.120 \\
(-1.38)\end{array}$ & 0.168 & $\begin{array}{l}-0.138 \\
(-1.59)\end{array}$ & 0.113 & $\begin{array}{l}-0.128 \\
(-1.49)\end{array}$ & 0.136 \\
\hline Contro & & & & & & & & \\
\hline $\begin{array}{l}\text { Agriculture \& } \\
\text { Manufacturing } \\
(\text { dummy) }\end{array}$ & $\begin{array}{l}0.053 \\
(1.02)\end{array}$ & 0.310 & $\begin{array}{c}0.062 \\
(1.22)\end{array}$ & 0.225 & $\begin{array}{r}0.067 \\
(1.36)\end{array}$ & 0.175 & & \\
\hline $\begin{array}{l}\text { Construction } \\
\left(_{\text {dummy })^{\mathrm{a}}}\right.\end{array}$ & $\begin{array}{r}0.037 \\
(0.75)\end{array}$ & 0.455 & $\begin{array}{l}0.033 \\
(0.65)\end{array}$ & 0.513 & $\begin{array}{l}0.034 \\
(0.69)\end{array}$ & 0.493 & & \\
\hline Services (dummy) ${ }^{\mathrm{a}}$ & $\begin{array}{c}0.104 \\
(1.55)\end{array}$ & 0.121 & $\begin{array}{l}0.099 \\
(1.49)\end{array}$ & 0.137 & $\begin{array}{l}0.094 \\
(1.45)\end{array}$ & 0.149 & & \\
\hline $\begin{array}{l}\text { Percentage with } \\
\text { no/low education }\end{array}$ & $\begin{array}{l}0.001 \\
(1.02)\end{array}$ & 0.306 & $\begin{array}{l}0.001 \\
(1.09)\end{array}$ & 0.278 & $\begin{array}{l}0.001 \\
(0.95)\end{array}$ & 0.340 & & \\
\hline $\begin{array}{l}\text { Percentage with } \\
\text { intermediate } \\
\text { education }^{c}\end{array}$ & $\begin{array}{l}0.000 \\
(-0.4)\end{array}$ & 0.689 & $\begin{array}{r}0.000 \\
(-0.43)\end{array}$ & 0.668 & $\begin{array}{l}0.000 \\
(-0.2)\end{array}$ & 0.845 & & \\
\hline Ln company age & $\begin{array}{l}-0.007 \\
(-0.37)\end{array}$ & 0.715 & $\begin{array}{l}-0.010 \\
(-0.57)\end{array}$ & 0.570 & $\begin{array}{l}-0.009 \\
(-0.53)\end{array}$ & 0.597 & & \\
\hline $\begin{array}{l}\text { 5-9 employees } \\
\text { (dummy) }^{\mathrm{b}}\end{array}$ & $\begin{array}{l}0.028 \\
(0.25)\end{array}$ & 0.799 & $\begin{array}{r}0.037 \\
(0.34)\end{array}$ & 0.737 & $\begin{array}{c}0.091 \\
(0.82)\end{array}$ & 0.415 & & \\
\hline$\geq \underset{(\text { dummy })^{\mathrm{b}}}{10 \text { employees }}$ & $\begin{array}{l}0.023 \\
(0.22)\end{array}$ & 0.829 & $\begin{array}{c}0.030 \\
(0.28)\end{array}$ & 0.777 & $\begin{array}{l}0.056 \\
(0.52)\end{array}$ & 0.604 & & \\
\hline$L P_{t-1, i}$ & & & & & $\begin{array}{l}-0.001 \\
(-5.28)\end{array}$ & 0.000 & $\begin{array}{l}-0.001 \\
(-5.41)\end{array}$ & 0.000 \\
\hline Constant term & $\begin{array}{l}-0.180 \\
(-0.94)\end{array}$ & 0.347 & $\begin{array}{l}-0.162 \\
(-0.84)\end{array}$ & 0.399 & $\begin{array}{l}-0.099 \\
(-0.52)\end{array}$ & 0.602 & $\begin{array}{c}0.023 \\
(0.30)\end{array}$ & 0.767 \\
\hline$R^{2}$ & 0.034 & & 0.052 & & 0.108 & & 0.087 & \\
\hline$F$ & $\left(\begin{array}{ll}10 & 366\end{array}\right)$ & $=0.98$ & $(12364)$ & $=1.80$ & $(13363)$ & $=3.18$ & $(5371)=$ & $=7.63$ \\
\hline$N$ & 377 & & 377 & & 377 & & 377 & \\
\hline
\end{tabular}

Notes: All models are estimated with OLS. Standard errors are calculated to be robust for heteroscedasticity and autocorrelation.

$F$ refers to the $F$-test on joint significance whereas $N$ denotes the number of cross-sectional units. a. Reference group: Hotel \& catering, Transport \& Communication, Financial Services, Wholesale and Retail Trade.

b. Reference group: 2-4 employees.

c. Reference group: higher education.

Coefficients significantly different from zero at least at the 10 per cent level are reported in bold letters.

Data sources: See Appendix 1. 
Model 4 also includes levels of labour productivity, but excludes the standard controls (size, age, education, sectors). As we can see, the signs of the coefficients are robust. Coefficients become slightly more significant when the model specification becomes more complete. In the more complete models (2-4), the significance level of internal flexibility practices rises from the 10 per cent almost to the 5 per cent level. The interaction between external flexibility practices and the Schumpeter II indicator is significantly negative at the 5 per cent level and becomes significant at the 1 per cent level in model 3, which includes all controls.

We performed two versions of the Ramsey reset test, to assess the appropriateness of including non-linearities (in this case: the interaction variable) in the regression. The first version tests for general non-linearities by regressing the residuals of model 1 on powers of the estimated values of that model. The powers of the estimated values can be seen as linear combinations of powers and interactions of the variables that enter in model 1 . The test yields a significant result $(F(3,360)=3.24 ; p=0.022)$, which points to the appropriateness of including powers and/or interactions in the model. To discriminate between the former and the latter, we perform a second version of the test. This version regresses powers of the independent variables on the residuals of model 1 . This version turns out to be insignificant $(F(24,339)=1.24 ; p=0.201)$. In conclusion, Ramsey's Reset test reaffirms our theoretical and empirical preference for including the interaction ExtFlex El $-1, i^{*} H H I$ in the model.

Simulations (not documented) show that an increase in external flexibility has little effect in sectors that tend towards a garage business regime, ${ }^{1}$ as the positive value of $\beta_{3}(H H I-\overline{H H I})$ is offset by the negative value of $\beta_{2}$, yielding a small and/or insignificant overall effect. It has, however, quite substantial and significantly negative effects among routinised innovators, as $\beta_{3}(H H I-\overline{H H I})$ turns negative and reinforces the negative effect of $\beta_{2}$. For example, in sectors that tend towards a routinised innovation regime, a 5-percentage-points increase in the share of flexible labour (in total personnel) reduces annual labour productivity growth by -0.6 percentage points (significant at 5 per cent level).

\section{DISCUSSION AND POLICY CONCLUSIONS}

In spite of supply-side attacks against the Keynesian welfare state since the 1970s, the Netherlands still have a welfare state and firing restrictions for tenured workers. But employers have the option of hiring flexible workers of various kinds. In practical life there is substantial variation between firms in the use of flexible arrangements. This offers the possibility of comparing firms that still have rather old-fashioned 'Rhineland' working relations to firms that tend towards 'flexible' Anglo-Saxon practices within one country and hence within an identical institutional framework.

An earlier study showed that flexibility is attractive to employers in one perspective: firms with high shares of flexible workers pay lower average wages (after control for age, qualification, sex, etc.). In the same study, however, it also turned out that rates of flexible workers had no impact on a firm's sales growth and this was due to flexible firms realising lower

1. We can calculate the marginal effect of a change in external flexibility on labour productivity growth $\left(\frac{\Delta \widehat{L P}}{\Delta E x t F l e x}\right)$ for empirical values of the Schumpeter II indicator, using the equation: $\frac{\Delta \widehat{L P}}{\Delta E x t F l e x}=\beta_{2}+\beta_{3}(H H I-\overline{H H I})$. Subdividing the Schumpeter II indicator into 4 quartiles, it turned out that, as expected, in the first two quartiles (that is, 'garage business' firms), changes in shares of flexible labour had only negligible effects. However, in the upper two quartiles (that is, among 'routinised innovators') we found significantly negative effects. 
labour productivity gains (see Kleinknecht et al. 2006). Seemingly, in terms of competitive strength, gains from paying lower wages tend to be compensated by weaker productivity performance.

This paper confirms earlier findings of a negative relationship between flexible personnel and labour productivity growth, but adds one further insight: the relationship is moderated by the type of innovation regime. Among 'garage business' innovators, the use of flexible workers neither enhances nor damages labour productivity growth. An explanation can be that garage business innovators tend to rely on general (and generally available) knowledge; seemingly, the loss of knowledge due to people leaving the firm seems to be more or less compensated by the gains from 'fresh blood' coming in. Other than in garage business, flexible workers have a very significantly negative impact on labour productivity among 'routine innovators'. Routine innovators depend on their historically accumulated (often tacit) knowledge base. In other words, a firm's technological competencies depend not only on its present R\&D, but also on the type of knowledge it happened to develop in the (long) past. Such historical path dependencies in knowledge production create barriers to entry which ensure monopoly profits that are an incentive for continued investment in R\&D. Also, because some of this knowledge is 'tacit' (that is, 'at people's fingertips'), high rates of personnel turnover will disturb knowledge accumulation. Under the routine regime, firms have an incentive to 'buy' the loyalty and commitment of workers by offering the perspective of long-run and safe employment. This reduces the probability of knowledge-leaking or other forms of disloyal behaviour. The need for longer-run commitments seems to plea against 'structural reforms' that make firing more easy and can enhance a culture of job-hopping. ${ }^{2}$

Nonetheless, those who plead for 'structural reforms' may, at first sight, be comfortable with our results: the Netherlands have high shares of flexible workers since 'insiders' are so strongly protected. As a consequence of insider protection, a firm's need for flexibility will increase the number of 'outsiders'. If structural reforms reduced the protection of insiders, the number of flexible outsiders might decline - and this would result in higher growth of labour productivity according to our model!

This line of reasoning neglects that the reality of 'structural reforms' does not need to be identical to its framing in public opinion. 'Structural reforms' are not about helping poor outsiders. They are aimed at changing power relations in the firm (notably through easy firing), thus changing income distribution which is hoped to improve the supply-side conditions for entrepreneurship. Supply-siders want a more 'dynamic' labour market with higher rates of labour turnover that are supposed to increase labour productivity as inefficient job matches can be more easily terminated. ${ }^{3}$ Moreover, lower protection of insiders allows firms to shed people more easily if risky innovation projects fail. Shifting risks to employees is supposed to encourage innovative new ventures (see for example Bartelsman et al. 2012).

2. Even if labour markets were deregulated, firms could of course still try to maintain 'high road' or 'collaborative' HRM policies which, according to Rizov/Croucher (2009), tends to be positively related to firm performance. They also report, however, that the relationship between 'collaborative HRM' and firm performance is weaker if firm-level policies are not supported by national institutional and normative settings. This could lead firms to abandon 'collaborative' HRM policies in response to 'structural reforms' of labour markets.

3. In its highly influential evaluation of political party programs for the 2012 national elections, the Netherlands Bureau for Economic Policy Analysis (CPB) attributed positive productivity effects to proposals for easier firing that allow for a higher labour turnover, although empirical findings (for example, Lucidi/Kleinknecht 2010) point exactly in the opposite direction. What a pity for our empirical outcomes that they are inconsistent with the theoretical assumptions in the CPB's econometric models! 
Another motive is that people should not be entrenched in safe jobs in which they lose creativity, and firms should have the sanction of easy firing in the case of shirking.

Of course, adherents of 'structural reforms' may argue that a legal possibility of easy firing does not need to prevent firms from keeping people for longer. The problem with this argument is that the mere legal possibility of easy firing will make people more mobile. Imagine, for example, that your firm shows poor performance. In this case, it may be rational to search proactively for a new job, before competition in your local labour market increases dramatically as your colleagues become aware of the threat of lay-offs. So you might leave your firm while your employer might not even have considered firing you.

In general, easy firing may enhance a culture of job-hopping; there is at least anecdotal evidence these days that successful IT firms in Silicon Valley suffer from high mobility of their personnel, in spite of offering good working conditions. From empirical research we know that personnel turnover is an important source of knowledge-leaking. For example, drawing from Community Innovation Survey data, Brouwer/Kleinknecht (1999) report that innovative firms in the Netherlands judge 'keeping qualified personnel in the firm' to be a crucial defence against imitators, being even more important than patent protection. This underlines the importance of tacit knowledge that can be protected through long job durations that create loyalty. While lower protection of insiders might reduce shares of outsiders, it is also likely to increase turnover rates of insiders who are carriers of crucial knowledge.

Finally, it is interesting to compare our firm-level results to outcomes at macro-level. There is evidence that Anglo-Saxon Liberal Market Economies $(L M E)$ show substantially lower wage increases than Coordinated Market Economies (CME), as their 'reformed' labour markets reduce the power of labour. Vergeer/Kleinknecht $(2011 ; 2014)$ show in panel data regressions for 19 OECD countries over 44 years that lower wage increases lead to significantly lower rates of labour productivity growth: a 1 per cent wage increase (or decline) leads to $\approx 0.4$ per cent higher (or lower) growth of GDP per labour hour. Indirectly, the results of this paper confirm the latter results: using higher shares of (cheaper) flexible outsiders leads to lower labour productivity growth at firm level. Many of the theoretical arguments in Section 2 above apply to both the firm- and the macro-level.

In this context, it should be mentioned that the hypothesis that wage restraint would reduce labour productivity growth is a hot issue in the Netherlands, as the country has had a long tradition of wage restraint ('loonmatiging') since 1982, being accompanied by poor labour productivity growth. There have been controversial discussions about whether wage restraint caused the productivity crisis (see for example Jansen 2004). Vergeer/ Kleinknecht $(2011 ; 2014)$ have therefore undertaken numerous efforts to check the robustness of their results. In the many versions of their models, coefficients range between 0.33 and 0.49 , the most plausible versions being close to 0.40 . Post-Keynesians should include the coefficient of 0.4 into their models in order to obtain a more complete picture of the effects of downward wage flexibility: besides the Keynesian demand effects of higher or lower wages, there are also neoclassical and productivity effects due to the substitution of capital for labour, vintage and creative destruction effects (see the discussion in Section 2 above).

No doubt, advocates of structural reforms of labour markets have one strong point: from the perspective of Walrasian General Equilibrium theory, flexible hire-and-fire guarantees (static) allocative efficiency! But Walrasians have no theory of (routine) innovation. One should also note that the field of innovation is full of market imperfections. In fact, we can define 'innovation' itself as a deliberate attempt to create an imperfect market: if I 
introduce a unique product or process that others have difficulty imitating, I have a source of monopoly profit. Unique knowledge that is hard to imitate acts as a market entry barrier; and the higher the entry barrier, the higher are my monopoly profits and hence my incentive to invest in $R \& D$.

The most important source of market failure is the strong public-good property of knowledge which makes legal protection of intellectual property rights hard to do. Copyrights, patents or trademarks can help but are far from perfect. We know that weak protection of property rights results in market failure - that is, in under-investment in knowledge or R\&D. Moreover, various sorts of information asymmetries and lock-in (owing to the sunk-costs character of innovative investments) can increase uncertainty and leave innovative efforts far below the social optimum. In any case, innovation is subject to strong technical and commercial uncertainties and failure rates are high; judging from the work of Edwin Mansfield (cited in Tidd/Bessant 2009), about half of all US private business R\&D is dedicated to projects that ultimately fail. Sure, in order to make firms nonetheless ready to invest in $R \& D$, they need to make high monopoly profits on the other half! And this is incompatible with the idea that 'more competition', let alone a perfectly competitive market, would enhance innovation, as was already observed by Schumpeter:

Perfect competition ... is a condition for optimal allocation of resources ... But ... introduction of new methods of production and new commodities is hardly conceivable with perfect ... competition ... And this means that the bulk of ... economic progress is incompatible with it. As a matter of fact, perfect competition is and always has been temporarily suspended whenever anything new is being introduced ... (Schumpeter 1943: 104-105)

The above implies that simply giving more room to 'free' markets is likely to result in stronger failure of markets with respect to bringing forth innovation. This is an admittedly hard message to market fundamentalists: market imperfections can be extremely useful for innovation, while impeding the efficient allocation of scarce resources in a static Walrasian perspective.

Recognising that market failure is the rule rather than exception, governments sometimes engage in policies that try to repair one market imperfection by introducing another one. For example, trademarks, copyrights or the patent system give a degree of monopoly power to creative people. In a Walrasian perspective, monopolies prevent an efficient allocation of scarce resources. In a Schumpeterian perspective, however, it is a highly desirable incentive for investment in creative but highly uncertain solutions.

Innovators need to have a prospect of high, and preferably longer-term, monopoly profits as an encouragement for risk-taking. And as innovations, with high investments in fixed (and often sunk) costs, require the use of scale economies, it is perhaps a blessing in disguise that anti-trust authorities often tolerate mergers that lead to dominant market positions. And finally, according to the logic of Schumpeter's (1943) routinised innovation model, we make the argument that labour market rigidities can be useful as longer job durations create loyalty. Loyalty makes the long-run accumulation of (tacit) knowledge easier; it allows using the knowledge from the shop floor for implementation of efficiency enhancing investments; it helps against knowledge-leaking and it economises on transaction costs for monitoring and control.

All these arguments might be summarised as follows: there is a significant trade-off between Walrasian static efficiency ('how can we allocate scarce resources efficiently?') and Schumpeterian dynamic efficiency ('how can we make resources less scarce through innovation?').

To conclude, the above may shed some light on the observation that, in spite of a highly flexible labour market, the US did quite well during the garage-business phase 
of IT during the 1980s and 1990s (for example, in Silicon Valley). Our outcomes might, however, also be an explanation for why, after the Reagan era, many classical industries in the US had a hard time competing against Japanese and German suppliers. It might explain why Detroit (rather than Wolfsburg) is today a dying city. Obviously, in recent years, the new giants in Silicon Valley are gradually shifting from garage business to path-dependent routine innovation. Our results above suggest that the US hire-and-fire labour market is no longer a favourable institutional environment for them.

\section{REFERENCES}

Acemoglou, D., Pischke, J.-S. (1999): Beyond Becker: training in imperfect labour markets, in: Economic Journal, 109, F112-F142.

Acharya, V., Ramin, P.B., Krishnamurthy, V.S. (2010): Labour laws and innovation, NBER Working Paper 16484, Cambridge, MA: National Bureau of Economic Research.

Agell, J. (1999): On the benefits from rigid labour markets: norms, market failures, and social insurance, in: Economic Journal, 109, 143-164.

Aiken, L.S., West, S.G. (1991): Multiple Regression: Testing and Interpreting Interactions, Newbury Park: Sage.

Albert, M. (1993): Capitalism Against Capitalism, London: Whurr.

Arvanitis, S. (2005): Modes of labor flexibility at firm level: are there any implications for performance and innovation? Evidence for the Swiss economy, in: Industrial and Corporate Change, 14, 993-1016.

Aubert, P., Crépon, B. (2006): Age, wage and productivity: firm-level evidence, Discussion Paper INSEE, Paris.

Auer, P., Berg, J., Coulibaly, I. (2005): Is a stable workforce good for productivity? in: International Labour Review, 144(3), 319-343.

Bartelsman, E., Gautier, P., de Wind, J. (2012): A less rigid firing protection will make the Netherlands more innovative and more productive [in Dutch], URL: www.mejudice.nl (accessed 18 June 2012).

Bassanini, A., Ernst, E. (2002): Labour market regulation, industrial relations and technological regimes: a tale of comparative advantage, in: Industrial and Corporate Change, 11(3), 391-426.

Bassanini, A., Nunziata, L., Venn, D. (2009): Job protection and productivity, in: Economic Policy, 24(58), 349-402.

Belot, M., Boone, J., Van Ours, J. (2002): Welfare effects of employment protection, CEPR Discussion Paper, No 3396.

Breschi, S., Malerba, F., Orsenigo, L. (2000): Technological regimes and Schumpeterian patterns of innovation, in: Economic Journal, 110, 288-410.

Brouwer, E., Kleinknecht, A. (1999): Innovative output and a firm's propensity to patent: an exploration of CIS micro data, in: Research Policy, 28, 615-624.

Buchele, R., Christiansen, J. (1999): Labour relations and productivity growth in advanced capitalist economies, in: Review of Radical Political Economics, 31, 87-110.

Dekker, R., Howing, H., Kösters, L. (2012): Turnover rates of flexible workers [in Dutch], in: Economisch Statistische Berichten, 97(4628), 70-73.

Dhondt, S., Vergeer, R., Kraan, K.O., Houtman, I.L.D., Vroome, E.M.M. de, Zwieten, M.H.J. van (2012): Quality of work, preventive measures and productivity: matching the NEWS sample to registration data [in Dutch], Hoofddorp: TNO.

Hall, P.A., Soskice, D. (2001): Varieties of Capitalism, Oxford: Oxford University Press.

Huselid, M. (1995): The impact of human resource management practices on turnover, productivity and corporate financial performance, in: Academy of Management Journal, 38, 635-670.

Jansen, W.J. (2004): The Kleinknecht hypothesis misses empirical evidence! [in Dutch], in: Economisch Statistische Berichten, 89(September), 418.

Kleinknecht, A. (1998): Is labour market flexibility harmful to innovation?, in: Cambridge Journal of Economics, 22, 387-396. 
Kleinknecht, A., Oostendorp, R.M., Pradhan, M.P., Naastepad, C.W.M. (2006): Flexible labour, firm performance and the Dutch job creation miracle, in: International Review of Applied Economics, 20, 171-187.

Kleinknecht, A., Van Schaik, F.N., Zhou, H. (2014): Is flexible labour good for innovation? Evidence from firm-level data, in: Cambridge Journal of Economics, 38(5), 1207-1219.

Lorenz, E.H. (1999): Trust, contract and economic cooperation, in: Cambridge Journal of Economics, 23, 301-316.

Lucidi, F., Kleinknecht, A. (2010): Little innovation, many jobs: an econometric analysis of the Italian labour productivity crisis, in: Cambridge Journal of Economics, 34, 525-546.

Malcomson, J.M. (1997): Contracts, hold-up, and labour markets, in: Journal of Economic Literature, 35, 916-957.

Martínez-Sánchez, A., Vela-Jiménez, M.J., Pérez-Pérez, M., de-Luis-Carnicer, P. (2008): Workplace flexibility and innovation: the moderator effect of inter-organizational cooperation, in: Personnel Review, 37(6), 647-665.

Michie, J., Sheehan, M. (2001): Labour market flexibility, human resource management and corporate performance, in: British Journal of Management, 12, 287-306.

Michie, J., Sheehan, M. (2003): Labour market deregulation, 'flexibility' and innovation, in: Cambridge Journal of Economics, 27, 123-143.

Naastepad, C.W.M., Kleinknecht, A. (2004): The Dutch productivity slowdown: the culprit at last?, in: Structural Change and Economic Dynamics, 15, 137-163.

Naastepad, C.W.M., Storm, S. (2006): The innovating firm in a societal context: labour-management relations and labour productivity, in: Verburg, R.M., Ortt, J.R., Dicke, W.M. (eds), Managing Technology and Innovation, London: Routledge, 170-191.

Nickell, S., Layard, R. (1999): Labour market institutions and economic performance, in: Ashenfelter, O., Card, D. (eds), Handbook of Labour Economics, Amsterdam: Elsevier Science, 3029-3084.

Oeij, P., de Vroome, E.M., Sanders, J.M.A.F., van den Bossche, S. (2009): Werkgevers Enquête Arbeid 2008: Methodologie en Beschrijvende Resultaten, Hoofddorp: TNO.

Pieroni, L., Pompei, F. (2008): Evaluating innovation and labour market relationships: the case of Italy, in: Cambridge Journal of Economics, 32(2), 325-347.

Podsakoff, P.M., MacKenzie, S.B., Lee, J.Y., Podsakoff, N.P. (2003): Common method biases in behavioral research: a critical review of the literature and recommended remedies, in: Journal of Applied Psychology, 88(5), 879-903.

Polanyi, M. (1966): The Tacit Dimension, Chicago: University of Chicago Press.

Rizov, M., Croucher, R. (2009): Human resource management and performance in European firms, in: Cambridge Journal of Economics, (33), 253-272.

Roca-Puig, V., Beltrán-Martín, I., Segarra Cipres, M. (2012): Combined effect of human capital, temporary employment and organizational size on firm performance, in: Personnel Review, 41 (1), 4-22.

Scarpetta, S., Tressel, T. (2004): Boosting productivity via innovation and adoption of new technologies: any role for labour market institutions?, Policy Research Working Paper Series 3273, Washington, DC: World Bank.

Schumpeter, J.A. (1912): Theorie der Wirtschaftlichen Entwicklung, Leipzig: Duncker \& Humblod.

Schumpeter, J.A. (1943): Capitalism, Socialism and Democracy, London: Allen \& Unwin.

Svensson, S. (2011): Flexible working conditions and decreasing levels of trust, in: Employee Relations, 34(2), 126-137.

Tidd, J., Bessant, J. (2009): Managing Innovation, 4th edn, Chichester, UK: Wiley.

Vergeer, R., Kleinknecht, A. (2011): The impact of labour market deregulation on productivity: a panel data analysis of 19 OECD countries (1960-2004), in: Journal of Post-Keynesian Economics, 33(2), 369-404.

Vergeer, R., Kleinknecht, A. (2014): Do labor market reforms reduce labor productivity growth? A panel data analysis of 20 OECD countries (1960-2004), in: International Labor Review, 153(3), 369-394. 


\section{APPENDIX 1: OUR THREE DATA SOURCES}

Our main source is The Netherlands Employers Work Survey 2008 (NEWS, in Dutch: Werkgevers Enquête Arbeid 2008) database, which was gathered in October 2008 (Oeij et al. 2009). The NEWS is a large-scale, bi-annual and representative questionnaire survey among Dutch companies. For this survey, a total of 15233 Dutch companies with at least two employees were approached through the Dutch LISA classification register. The sample is stratified by industry and company size. Respondents were first contacted by telephone and then received an internet link to an online questionnaire. The net response rate (35 per cent) consisted of 5387 affiliations of companies and (not-for-profit and public) institutions. The respondents were directors or HR managers. The response group is representative of the population of all organisations in the country that employ labour. For more information, we refer to the report Employers Labour Survey 2008: Methodology and Descriptive Results (www.tno.nl/wea). From this database we use data for our indicator of internal flexibility and for all the control variables.

The NEWS sample was merged with balance-sheet data and wage-tax registration statistics from Statistics Netherlands. The balance-sheet database covers all firms with a balance total of $>€ 23$ million and a random sample of firms with a balance total of $<€ 23$ million. The matching process of our NEWS 2008 data with the balance-sheet data leads to a substantial reduction of numbers of observations. There are two main reasons for the reduction of observations. First, the balance-sheet data are at enterprise level, while many observation units in the NEWS sample are affiliations. The latter had to be omitted for the sake of consistency. Second, both the NEWS and the balance-sheet data are sampling smaller firms with a balance total of $<€ 23$ million which directly implies that we lose many observations. Furthermore, we eliminated outliers according to the method proposed by Aubert/Crepon (2006) and removed not-for-profit and public sector organisations as the latter have no measurable productivity performance. Finally, we only included companies that had no item non-response on the relevant variables. All in all, this resulted in a data set with 377 valid observations. We tested representativeness of the matched subsample in an earlier study (Dhondt et al. 2012) by comparing the distribution of firms over sectors, firm size classes and other indicators with that of the total WEA sample. We found that the shape of the distributions are roughly similar. Only smaller companies and companies in manufacturing, construction, and transport \& logistics are slightly overrepresented.

Balance Sheet Statistics for Non-Financial Firms (in Dutch: Statistiek Niet-Financiële Ondernemingen, NFO) were obtained from Statistics Netherlands (CBS). The data consist of a sample of balance sheet and annual account data for smaller and larger firms. For smaller firms, the data set covers a sample of 150000 firms; for larger firms the data consist of a registration of 2500 firms. We constructed our measure for value added (as a component of labour productivity) from this database.

Wage-Tax Registrations Statistics (in Dutch: Loonaangifte statistieken, LA) are also collected by Statistics Netherlands. This data set covers all income tax statistics of all taxed employees in the Netherlands. We constructed our objective measure for external flexibility and the number of FTEs per firm from the latter database. We calculated labour productivity as the ratio of value added over employees (full-time equivalents) at firm level. 
316 European Journal of Economics and Economic Policies: Intervention, Vol. 12 No. 3

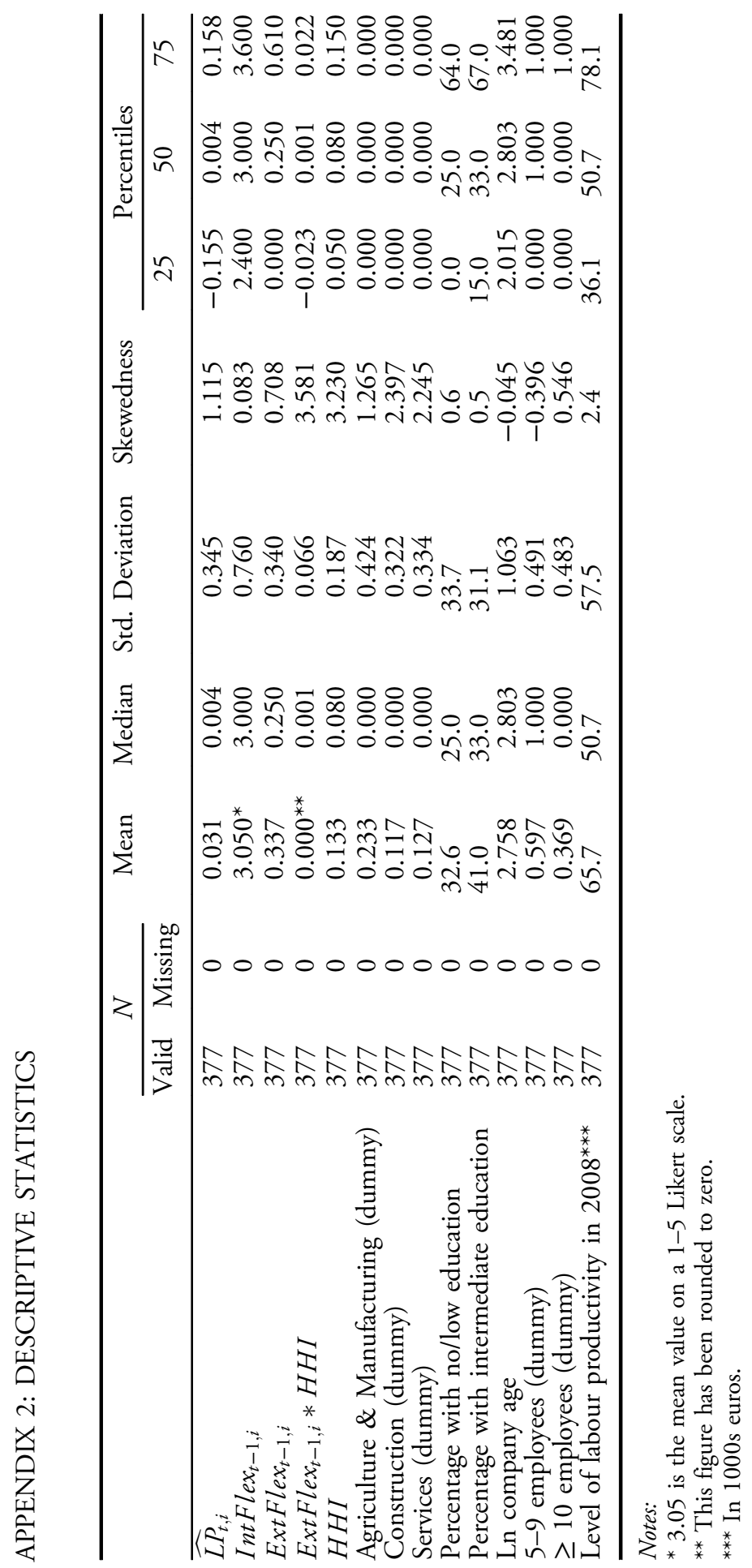




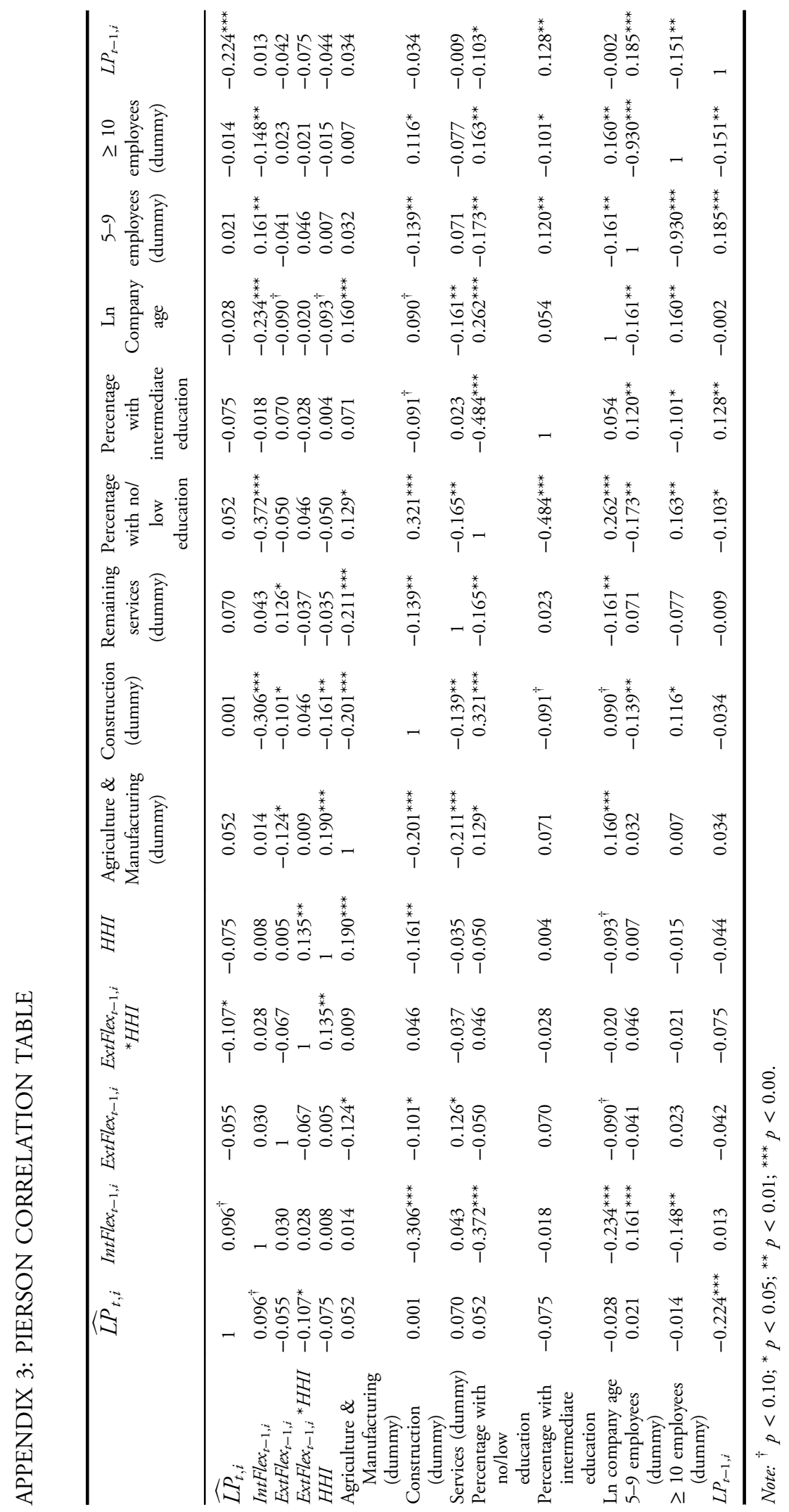

